\title{
Lodging Resistance and Yield Performance of Two Traditional Rice Varieties Applied with Nitrogen and Paclobutrazol
}

\author{
Ariel G. Mactal and Justo G. Canare Jr. \\ College of Agriculture, Central Luzon State University, Science City of Muñoz, \\ Nueva Ecija, 3120, Philippines
}

\section{ABSTRACT}

Vulnerability of rice growing areas to strong typhoons coupled by the susceptibility of traditional rice varieties to lodging lead to low yield and poor quality of harvested rice. To address these problems, two experiments using factorial in Randomized Complete Block Design were conducted during the wet season to determine the effects of paclobutrazol and nitrogen on the lodging resistance, agro-morphological characteristics and yield performance of two traditional rice varieties Elon-elon and Palawan Red. Application of increasing concentration of paclobutrazol did not significantly affect the percentage filled spikelets per panicle, number of spikelets per panicle, weight of 1000 grains, dry matter yield, harvest index and grain yield. At all concentrations of paclobutrazol, Palawan red had the longest first and fourth internodes, more unfilled spikelets per panicle, heavier 1000 grains weight and higher leaf area index than Elonelon. On the other hand, smaller stem diameter, more productive tillers per hill and longer panicles were obtained from Elon-elon than Palawan red. Elon-elon applied with increasing rates of nitrogen in combination with $500 \mathrm{ppm}$ paclobutrazol had bigger stem diameter, higher productive tillers per hill, higher number of filled spikelets per panicle, higher percentage filled spikelets per panicle, longer panicles, higher harvest index and higher grain yield than Palawan red. Apparently, Palawan red had longer first, second and third internodes, more unfilled spikelets per panicle, heavier 1000 grain weight and higher leaf area index than Elon-elon. Applications of 30 and $60 \mathrm{~kg} \mathrm{~N}$ per ha had significantly higher lodging index than the untreated plants. Harvest index and grain yield were lowest in plants applied with 30 and $60 \mathrm{~kg} \mathrm{~N}$ per ha, attributable to high lodging index. Paclobutrazol is effective in shortening the length of the lower internodes and inhibits stem elongation resulting to shorter plants with increased lodging resistance. This ultimately produced higher yield than those plants that lodged. Culm strength was reduced by high rates of nitrogen causing significant increase in lodging index. The time of lodging is crucial in predicting the yield performance of the plants.

Correspondence: Ariel G. Mactal Address: College of Agriculture, Central Luzon State University, Science City of Muñoz, Nueva Ecija, Philippines. Mobile Number: 0920-9267854

E-mail:ariel_mactal@yahoo.com

DOI: 10.32945/atr3828.2016 
Early lodging resulted to huge reduction in yield while it has little or no effect on yield when it occurs at later stages of the rice crop.

Keywords: lodging index, Paclobutrazol, lodging incidence, stem elongation

\section{INTRODUCTION}

Lodging is one of the most serious and extensive problems in rice production. It has been responsible for limiting the yield as well as lossesin harvestable yields in cereals globally. Yieldlosses can be up to $80 \%$ and can cause severe knock-on effects, including reduced grain quality and greater drying cost (Berry et al. 2004). In the Philippines, lodging due to strong typhoons causes significant reduction in the yield of rice. Typhoons, floods, and droughts caused $82.4 \%$ of the total Philippine rice losses from 1970 to 1990. Early lodging can severely reduce yield and is generally deleterious to grain quality (Ueno et al. 1987).

Lodging usually results from the bending or buckling of the two lowest internodes, which have elongated more than $4 \mathrm{~cm}$. (Yoshida, 1981). One of the solutions which can be adopted to abate this problem is to manipulate the growth and development of rice to improve the lodging resistance and height characteristics. Lodging resistance is dependent on the mechanical strength, chemical composition and plant nutritional status of the elongated internodes (Yoshida, 1981). Early studies show that exogenous application of paclobutrazol reduced culm length by $10-15 \%$ by paclobutrazol application, (Im et al. 1987) and the yield increased by 15$26 \%$ in paclobutrazol applied plants over the control (Im et al. 1988). However, the problems on lodging is complicated by the heavy application of nitrogen fertilizers. Mengel and Kirkby (1987) stated that high rates of nitrogen caused lodging in cereals and increased the susceptibility of crop to fungal diseases, decreases filled-spikelet percentage, reduces the crosssectional area of vascular bundles and disturbs the movement of assimilates and absorbed nutrients via the roots Yoshida and Parao (1976) as cited by Yoshida (1981). Mahbub et al. (2006) showed that with the increase of added nitrogen, bending moment of all varieties gradually increased which might be due to the increase in elongation of internode at higher nitrogen level. Culm strength gradually decreased with the increase of nitrogen fertilizer in all the varieties.

Two traditional varieties; both susceptible to lodging, are commonly grown for their good eating quality. Palawan Red is a tall variety, with long and broad leaves. The grains are long and awnless with red caryopsis pericarp color. Likewise, Elon-elon is tall with semi- erect, intermediately long and narrow leaf blade. The grains are also awnless, medium to round in appearance with white caryopsis pericarp color. Since the optimum nitrogen requirement of rice differs significantly between wet and dry 
seasons due to the difference in the intensity of solar radiation and temperature during the growth period (Akita et al. 1987), a closer look at the effects of paclobutrazol and nitrogen on Elon-elon and Palawan red is undertaken.

The study was undertaken to determine the effects of paclobutrazol and nitrogen on the lodging resistance, agro-morphological characteristics and yield performance of Elon-elon and Palawan Red. Specifically it aimed to:

1. determine the effects of different concentrations of paclobutrazol on stem elongation of Elon-elon and Palawan red and ultimately on various agronomic characteristics;

2. evaluate the resistance to lodging of Elon-elon and Palawan red applied with paclobutrazol, and;

3. evaluate the effects of paclobutrazol on lodging resistance of Elonelon and Palawan red applied with various levels of nitrogen.

\section{MATERIALS AND METHODS}

Two studies were conducted in wet season at a farmer's field in the Science City of Muñoz, Nueva Ecija to evaluate the effects of paclobutrazol and nitrogen on lodging resistance, agronomic and yield performance of Elon-elon and Palawan Red. The experimental area falls under the Type-I climate with two pronounced seasons; wet from May to October and dry from November to April. The soil belongs to Maligaya clay loam with low total $\mathrm{N}$, deficient available $\mathrm{P}$ and deficient exchangeable $\mathrm{K}$. The soil has moderately acidic $\mathrm{pH}$ with medium organic matter content.

\section{Experimental design and treatments}

Study 1 was conducted using factorial in Randomized Complete Block Design (Gomez, K.A and A.A. Gomez, 1984). It is focused on determining the effects of different concentrations of paclobutrazol on lodging resistance and the agronomic and yield performance of Elon-elon and Palawan Red. An area of $512 \mathrm{~m}^{2}$ was thoroughly prepared and was divided to three blocks representing the number of replication and each block was subdivided to eight plots to represent the number of treatment combinations. Each plot had a dimension of $5 \mathrm{~m} \times 4 \mathrm{~m}$. The blocks were spaced $1 \mathrm{~m}$ from each other to facilitate irrigation and easy movement of personnel in the experimental area. The treatments were:

$$
\begin{array}{ll}
\text { Factor A (Variety) } & \text { Factor B (Concentration of Paclobutrazol) } \\
\text { A1 - Elon-elon } & \text { B1 - } 0 \mathrm{ppm} \\
\text { A2 - Palawan Red } & \text { B2 }-250 \mathrm{ppm} \\
& \text { B3 }-500 \mathrm{ppm} \\
& \text { B4- } 1000 \mathrm{ppm}
\end{array}
$$


Study 2 was focused on determining the effects of different levels of nitrogen on the agro-morphological and yield performance of Elon-elon and Palawan red applied with paclobutrazol. It was conducted using factorial in RCBD utilizing an area with a size of $384 \mathrm{~m}^{2}$. It had the following treatments;

Factor A (Variety)

A1 - Elon-elon

A2 - Palawan Red
Factor B (Level of Nitrogen)

$$
\begin{aligned}
& \text { B1 - } 0(\mathrm{~kg} \mathrm{~N} / \mathrm{ha}) \\
& \text { B2 - } 30(\mathrm{kgN} / \mathrm{ha}) \\
& \text { B3 - } 60(\mathrm{~kg} \mathrm{~N} / \mathrm{ha})
\end{aligned}
$$

The rice plants were sprayed with paclobutrazol at a concentration of $500 \mathrm{ppm}$ at $19 \mathrm{DAT}$.

Seedling Establishment

Pre-germinated seeds of the two traditional rice varieties were sown separately in a well-prepared seedbed, following the rate of $40 \mathrm{~kg}$ seeds per $400 \mathrm{~m}^{2}$ as recommended by PhilRice.

\section{Transplanting}

Twenty-one-day-old seedlings of the two traditional rice varieties were transplanted to the experimental area immediately after pulling. The seedlings were transplanted at a distance of $25 \mathrm{~cm}$ x $25 \mathrm{~cm}$, maintaining two seedlings per hill.

\section{Fertilization}

The recommended amount of fertilizer was determined through soil chemical analysis. The fertilizer rate of 30-60-30 (kg N-P $\left.\mathrm{O}_{5}-\mathrm{K}_{2} \mathrm{O}\right)$ was supplied using urea (46-0-0), ordinary super phosphate $(0-18-0)$ and muriate of potash (0-0-60). For Sub-study 2, the recommended level of $P$ and $\mathrm{K}$ was used while $\mathrm{N}$ levels vary depending on the treatments being tested. The fertilizer materials were applied in two splits; five days after transplanting (DAT) and 30 DAT.

\section{Application of Paclobutrazol}

Paclobutrazol, chemical name (2RS, 3RS)-1-(4-Chlorophenyl)-4, 4dimethyl-2-(1H-1, 2, 4-triazol-1-yl) pentan-3-ol) with a concentration of $10 \%(10 \mathrm{WP})$. It is a stable, white crystalline solid that is soluble in water. It is a plant growth retardant and triazole fungicide that is a known opponent of the plant hormone gibberellin. It acts by inhibiting gibberellin biosynthesis by inhibiting oxidation of kaurene. 
This in turn reduces the rate of cell division, the morphological consequence of being a reduction in stem elongation (Ueno and Kohli, 1994). It was applied at the stage of growth before the internode elongation. In photosensitive and late maturing varieties, this usually occurs before the panicle primordia initiation (Yoshida, 1981). In this study, paclobutrazol was sprayed at tillering stage or 19 DAT using a knapsack sprayer.

\section{Care and Maintenance}

The recommended technology for rice production prepared by PhilRice was followed in the proper care and maintenance of the plants. Spraying of molluscide at transplanting, pre-emergent herbicide at $3 \mathrm{DAT}$, and spraying of insecticides and fungicides were done at 15, 30, 45 and 60 DAT. Water was maintained at a recommended depth of 2 to $3 \mathrm{~cm}$ at vegetative stage, increasing it to $5 \mathrm{~cm}$ at reproductive stage. Water was withdrawn for about seven days at tillering stage to encourage tiller development. One week prior to harvesting, water was totally withdrawn from the field.

\section{Data Gathered}

The gathering of data was done following the Standard Evaluation System for Rice (IRRI, 1988), Field Operations Manual (PhilRice, 2007) and the Techniques for Field Experiments with Rice (Gomez, 1972). The lodging incidence was determined using the scale set by IRRI (1988) as follows:

Lodging Index
0
1
3
5
7
9

Description
no lodging
less than $20 \%$
$20-40 \%$
$41-60 \%$
$61-80 \%$
more than $80 \%$

Analysis of Data

The data were statistically analyzed using the SAS version 9.0 software following the Factorial in RCBD. Comparison among means was determined using the Duncan's Multiple Range Test (DMRT).

\section{RESULTS AND DISCUSSION}

Study I - Effects of Paclobutrazol Concentration on the Agro-morphological and Yield Performance of Elon-elon and Palawan red 
Stem Diameter, Culm Length, and Plant Height at Maturity

Stem diameter, culm length and plant height at maturity are some agronomic characters that affect the lodging susceptibility of the rice plant. Short plants with large stems are generally sturdy and are difficult to lodge despite strong winds. According to Yoshida (1981), if all other things are equal, a tall variety has a greater bending moment than a short variety because it has greater culm height.

Stem diameter at maturity was not significantly affected by the different concentration of paclobutrazol, and their interaction (Table 1). On the other hand, culm length and plant height at maturity were significantly decreased by the application of paclobutrazol at $1000 \mathrm{ppm}$ but not at lower concentrations.

Table 1. Stem diameter $(\mathrm{mm})$, culm length $(\mathrm{cm})$ and plant height $(\mathrm{cm})$ as affected paclobutrazol concentration

\begin{tabular}{cccc}
\hline $\begin{array}{c}\text { Paclobutrazol } \\
\text { Concentration } \\
(p p m \text { a.i..) }\end{array}$ & $\begin{array}{c}\text { Stem } \\
\text { Diameter } \\
(\mathrm{m} \mathrm{m})\end{array}$ & $\begin{array}{c}\text { Culm } \\
\text { Length } \\
(\mathrm{cm})\end{array}$ & $\begin{array}{c}\text { Plant } \\
\text { Height } \\
(\mathrm{cm})\end{array}$ \\
\hline 0 & 6.24 & $110.27^{\mathrm{b}}$ & $133.75^{\mathrm{b}}$ \\
250 & 6.39 & $110.70^{\mathrm{b}}$ & $134.89^{\mathrm{b}}$ \\
500 & 6.22 & $105.14^{\mathrm{ab}}$ & $128.91^{\mathrm{ab}}$ \\
1000 & 6.12 & $96.57^{\mathrm{a}}$ & $120.92^{\mathrm{a}}$ \\
\hline
\end{tabular}

Means in a column followed by the same letter superscript (s) are not significantly different at $5 \%$ level by DMRT

There was a reduction of $12.42 \%$ on culm length and $9.59 \%$ on plant height compared to the untreated plants. These findings are also consistent to the findings of Im et al. (1987), which showed that culm length was shortened by $10-15 \%$ due to paclobutrazol application.

Elon-elon have bigger stem diameter than Palawan red which is due to the difference in their inherent genetic make-up (Table 2). Culm length and plant height at harvest of Elon-elon and Palawan Red were comparable with each other.

Table 2. Stem diameter $(\mathrm{mm})$, culm length $(\mathrm{cm})$ and plant height $(\mathrm{cm})$ of Elon-elon and Palawan Red varieties

\begin{tabular}{cccc}
\hline Variety & $\begin{array}{c}\text { Stem } \\
\text { Diameter } \\
(\mathrm{m} \mathrm{m})\end{array}$ & $\begin{array}{c}\text { Culm } \\
\text { Length } \\
(\mathrm{cm})\end{array}$ & $\begin{array}{c}\text { Plant } \\
\text { Height } \\
\text { (cm) }\end{array}$ \\
\hline Elon-elon & $6.41^{\mathrm{a}}$ & 103.68 & 127.97 \\
Palawan Red & $6.07 \mathrm{~b}$ & 107.65 & 131.26 \\
\hline \hline
\end{tabular}

Means in a column followed by the same letter superscript (s) are not significantly different at $5 \%$ level by DMRT 


\section{Length of Lower Internodes at Maturity}

Determination of the length of lower internodes is crucial in relation to lodging index. Lodging in rice usually results from the bending or buckling of the two internodes, which have elongated more than $4 \mathrm{~cm}$. The strength of the elongated internodes is affected by the mechanical strength, chemical composition and plant nutritional status. If all other things are equal, a tall variety would have a greater bending moment than a short variety because it has greater culm height (Yoshida, 1981).

Paclobutrazol concentration at higher levels reduced the lengths of the second and third internodes only, while significant variations between varieties were observed in all the four internodes considered (Tables 3, 4 and 5). Furthermore, paclobutrazol concentration and variety had interaction effects on the length of the third internode.

Table 3. Length of first, second and fourth internodes at maturity ( $\mathrm{cm}$ ) as affected by paclobutrazol concentration

\begin{tabular}{cccc}
\hline $\begin{array}{c}\text { Paclobutrazol } \\
\text { Concentration } \\
\text { (ppm a.i.) }\end{array}$ & \multicolumn{3}{c}{ Length of Internodes (cm) } \\
\cline { 2 - 4 } 0 & First & Second & Fourth \\
\hline 250 & 5.21 & $10.64^{\mathrm{b}}$ & 21.28 \\
500 & 5.44 & $9.34^{\mathrm{b}}$ & 22.06 \\
1000 & 4.72 & $7.65^{\mathrm{ab}}$ & 19.94 \\
\hline \hline
\end{tabular}

Means in a column followed by the same letter superscript (s) are not significantly different at $5 \%$ level by DMRT

Paclobutrazol significantly reduced the length of the second and third internodes. The reduction started at $500 \mathrm{ppm}$ level and became more evident at $1000 \mathrm{ppm}$ level (Table 5). The length of the second internode was reduced by $44.45 \%$, while the third internode by $28.09 \%$ due to the application of $1000 \mathrm{ppm}$ paclobutrazol compared to untreated plants.

Table 4. Length of first, second and fourth internodes at maturity $(\mathrm{cm})$ of two traditional rice varieties

\begin{tabular}{lccc}
\hline \hline Variety & \multicolumn{3}{c}{ Length of Internodes (cm) } \\
\cline { 2 - 4 } & First & Second & Fourth \\
\hline Elon-elon & $3.87^{\mathrm{a}}$ & $6.89^{\mathrm{a}}$ & $17.62^{\mathrm{a}}$ \\
Palawan Red & $5.86^{\mathrm{b}}$ & $9.88^{\mathrm{b}}$ & $22.91^{\mathrm{b}}$
\end{tabular}

Means in a column followed by the same letter superscript (s) are not significantly different at $5 \%$ level by DMRT 
The effect of paclobutrazol was further highlighted by the interaction effect on the third internode (Table 5). The length of the third internode of Elon-elon was reduced by paclobutrazol but only at $1000 \mathrm{ppm}$. However, paclobutrazol did not affect the length of the third internode of Palawan Red.These results conform to the findings of Im et al. (1987) that culm length was shortened by $10-15 \%$ by paclobutrazol application.

Table 5. Length of third internode $(\mathrm{cm})$ of two traditional rice varieties as affected by paclobutrazol concentration

\begin{tabular}{cccccc}
\hline Variety & \multicolumn{4}{c}{ Paclobutrazol Concentration } & (ppm) \\
\cline { 2 - 5 } & 0 & 250 & 500 & 1000 & Mean \\
\hline Elon-elon & $13.61^{\mathrm{b}}$ & $13.84^{\mathrm{b}}$ & $13.04^{\mathrm{b}}$ & $6.82^{\mathrm{a}}$ & $11.83^{\mathrm{A}}$ \\
Palawan Red & $18.86^{\mathrm{b}}$ & $18.26^{\mathrm{b}}$ & $12.93^{\mathrm{b}}$ & $16.53^{\mathrm{b}}$ & $16.64^{\mathrm{B}}$ \\
Mean & $16.23^{\mathrm{x}}$ & $16.05^{\mathrm{x}}$ & $12.98^{\mathrm{y}}$ & $11.67^{\mathrm{y}}$ & \\
\hline \hline
\end{tabular}

*Means in a column followed by the same letter superscript (s) are not significantly different at $5 \%$ level by DMRT

\section{Lodging Index}

Lodging index of traditional rice varieties as affected by increasing concentrations of paclobutrazol is shown in Table 6. Lodging indices of Elon-elon and Palawan red did not vary significantly at all concentrations of paclobutrazol tested.

Increasing the concentration of paclobutrazol from 0 to $1000 \mathrm{ppm}$ significantly decreased the lodging index of traditional varieties. The general trend is similar to that of the lengths of the second and third internodes, culm length and plant height. This result confirms the findings of Street et al. (1986) that application of $0.28 \mathrm{~kg}$ a.i./haof paclobutrazol two weeks after panicle initiation reduced rice height each year and increased rough rice yield in two of three years. Lodging, which occurred in only one of three years, was significantly decreased with $0.28 \mathrm{~kg}$ a.i./ha of paclobutrazol applied eitherat panicle initiation or two weeks after panicle initiation.

Table 6. Lodging index as affected by paclobutrazol concentration

\begin{tabular}{cc}
\hline $\begin{array}{c}\text { Paclobutrazol Concentration } \\
\text { (ppm a.i.) }\end{array}$ & Lodging Index \\
\hline 0 & $7.67 \mathrm{c}$ \\
250 & $5.33 \mathrm{~b}$ \\
500 & $2.83 \mathrm{ab}$ \\
1000 & $0.33 \mathrm{a}$ \\
\hline
\end{tabular}

Means in a column followed by the same letter superscript(s) are not significantly different at $5 \%$ level by DMRT. 
The relationship between paclobutrazol concentration and lodging index are linear. Lodging index is described by the equation $\mathrm{Y}=-0.007 \mathrm{x}+$ 7.234 which means that for every unit increase in the concentration of paclobutrazol (ppm), lodging index decreased by 0.007 unit.

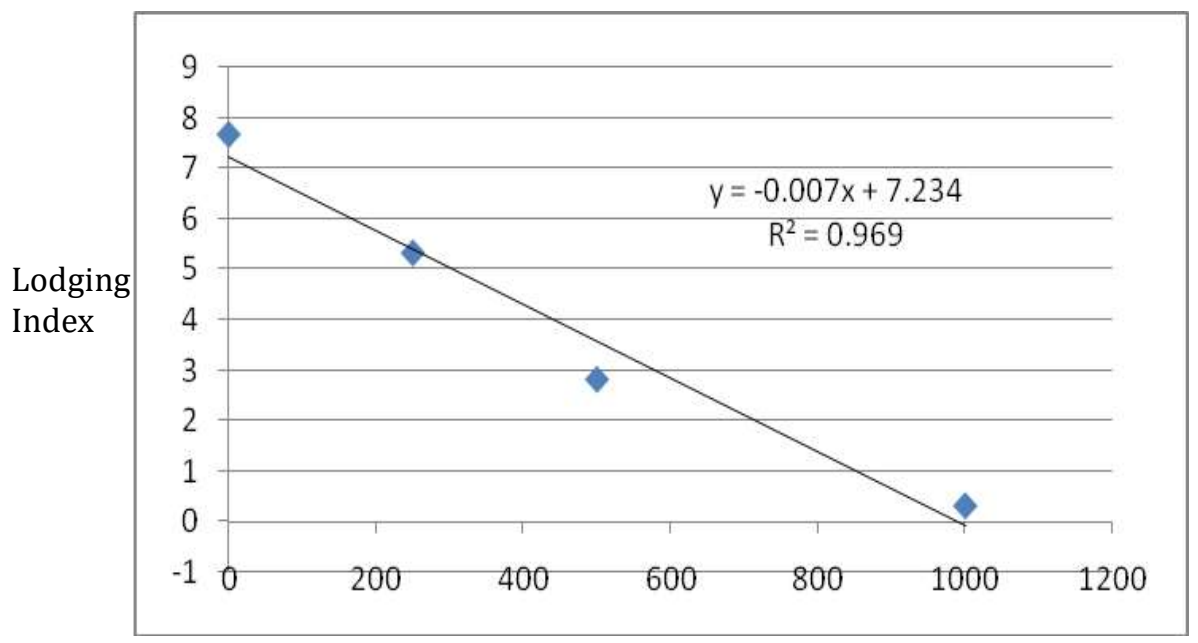

Concentration of paclobutrazol (ppm a.i.)

Figure 1. Relationship of paclobutrazol concentration and lodging index

\section{Leaf Area Index}

Table 7 and 8 present the leaf area index (LAI) which indicates the proportion of leaf surface area to the ground area which the plant occupies. A LAI of five to six is necessary to achieve maximum crop photosynthesis during the productive stage. During ripening, the LAI will decrease as grain filling proceeds and leaf senescence occurs (Yoshida, 1981). Results disclosed that LAI was not affected by the concentrations of paclobutrazol, while it varies among the two varieties used. As dictated by their genetic make-up, Palawan Red had higher LAI than Elon-elon. The inherent character of Palawan Red of having long and broader leaves caused the significant difference on their leaf area.

Table 7. Leaf area index as affected by paclobutrazol concentration

\begin{tabular}{cc}
\hline \hline $\begin{array}{c}\text { Paclobutrazol Concentration } \\
(\mathrm{ppm} \text { a.i. })\end{array}$ & Leaf Area Index \\
\hline 0 & 2.89 \\
250 & 3.13 \\
500 & 3.53 \\
1000 & 2.94 \\
\hline
\end{tabular}


Table 8. Leafarea index of two traditional rice varieties

\begin{tabular}{lc}
\hline Variety & Leaf Area Index \\
\hline Elon-elon & $2.59^{\mathrm{a}}$ \\
Palawan Red & $3.65^{\mathrm{b}}$ \\
\hline \hline
\end{tabular}

Means in a column followed by the same letter superscript (s) are not significantly different at $5 \%$ level by DMRT

\section{Number of Productive and Unproductive Tillers per Hill Index}

The number of productive tillers per hill significantly differed among varieties, while the number of unproductive tillers of the two traditional varieties were comparable (Table 9). Elon-elon produced significantly more productive tillers than Palawan Red, with an average of 15 and 11, respectively (Table 10).

Table 9. Number of productive and unproductive tillers per hill as affected by paclobutrazol concentration

\begin{tabular}{ccc}
\hline \hline Paclobutrazol & & \\
Concentration & Number of Tillers Per Hill \\
\cline { 2 - 3 } (ppma.i.) & Productive & Unproductive \\
\hline 0 & 14 & 1 \\
250 & 13 & 2 \\
500 & 13 & 2 \\
1000 & 13 & 2 \\
\hline \hline
\end{tabular}

Means in a column followed by the same letter superscript(s) are not significantly different at $5 \%$ level by DMRT

Spraying with paclobutrazol did not affect tiller production. In addition, the interaction effects of variety and concentration of paclobutrazol were not significant. As previously hypothesized, early application of paclobutrazol to transplanted rice would result to an increase in the number of productive tiller. The above results did not attain any positive response.

Table 10. Number of productive and unproductive tillers per hill of two traditional rice varieties

\begin{tabular}{ccc}
\hline \hline Variety & \multicolumn{2}{c}{ Number of Tillers Per Hill } \\
\cline { 2 - 3 } & Productive & Unproductive \\
\hline Elon-elon & $15^{\mathrm{a}}$ & 2.0 \\
Palawan Red & $11^{\mathrm{b}}$ & 2.0 \\
\hline
\end{tabular}

Means in a column followed by the same letter superscript (s) are not significantly different at $5 \%$ level by DMRT 
Unlike in the study of Wang et al. (1988), muti-effect triazole (MET) applied at $300 \mathrm{ppm}$ to the seedlings of late rice at $1 \sim 2$ leaf stage showed high effectivity in controlling plant height and promoting tillering of rice seedlings. The seedlings sprayed with MET did fade after transplanting. The plant height was reduced as much as 30\%; and the tillers of seedlings increased as much as 50\%. Wang (1991) mentioned that soaking or spraying the seeds with 100 to 300 ppm MET was highly effective in retarding plant height and promoting tillering of rice seedling. This finding suggests that tillering capability of rice is enhanced by paclobutrazol when sprayed at seedling stage.

It is worthwhile mentioning that in this experiment, spraying of paclobutrazol was affected by strong rain;There was strong rain when paclobutrazol was sprayed in the morning and at four oclock in the afternoon. It is possible that the full effect of the sprayed paclobutrazol was not obtained and resulted to nonconformity with previous studies. Spraying of paclobutrazol at tillering stage needs further study.

Panicle Length, Number of Unfilled Grains per Panicle and Number of Spikelets per Panicle

Table 11 presents the panicle length $(\mathrm{cm})$, number of unfilled spikelets per panicle and number of spikelets per panicle as affected by paclobutrazol concentration. The number of spikelets per panicle indicates the yield capacity of rice. When conditions are favorable, those plants with more spikelets have higher yield capacities.

Results disclosed that paclobutrazol concentration did not significantly affect the above parameters. Elon-elon and Palawan Red had comparable panicle lengths and number of spikelets per panicle (Table 12). This can be attributed to the difference in their genetic make-up.

Table 11. Panicle length $(\mathrm{cm})$, number of unfilled spikelets per panicle and number of spikelets per panicle as affected by paclobutrazol concentration

\begin{tabular}{cccc}
\hline $\begin{array}{c}\text { Paclobutrazol } \\
\begin{array}{c}\text { Concentration } \\
\text { (ppm) }\end{array}\end{array}$ & $\begin{array}{c}\text { Panicle } \\
\text { Length } \\
\text { (cm) }\end{array}$ & $\begin{array}{c}\text { Number of } \\
\text { Unfilled } \\
\text { Spikelets/ } \\
\text { Panicle }\end{array}$ & $\begin{array}{c}\text { Number of } \\
\text { Spikelets/ } \\
\text { Panicle }\end{array}$ \\
\hline 0 & 23.48 & 32.6 & 94.43 \\
250 & 24.19 & 27.08 & 109.59 \\
500 & 23.77 & 30.08 & 113.19 \\
1000 & 24.35 & 25.83 & 98.65 \\
\hline
\end{tabular}

Elon-elon produced an average of 24.71 unfilled spikelets per panicle (Table 12). This value was significantly lower than the number of unfilled spikelets produced by Palawan Red with a value of 33 spikelets per panicle. This result can be explained by the effect of strong rains during the peak 
of flowering of Palawan Red, which occured earlier than Elon-elon.

Table 12. Panicle length $(\mathrm{cm})$, number of unfilled spikelets per panicle and number of spikelets per panicle of two traditional rice varieties

\begin{tabular}{cccc}
\hline & $\begin{array}{c}\text { Panicle } \\
\text { Length } \\
(\mathrm{cm})\end{array}$ & $\begin{array}{c}\text { Number } \\
\text { of Unfilled } \\
\text { Spikelets/Panicle }\end{array}$ & $\begin{array}{c}\text { Number of } \\
\text { Spikelets } \\
\text { Panicle }\end{array}$ \\
\hline $\begin{array}{c}\text { Elon-elon } \\
\text { Palawan } \\
\text { Red }\end{array}$ & 24.28 & $24.71^{\mathrm{b}}$ & 99.16 \\
& 23.61 & $33.09 \mathrm{a}$ & 108.78 \\
\hline
\end{tabular}

Means in a column followed by the same letter superscript(s) are not significantly different at $5 \%$ level by DMRT

\section{Number of Filled Spikelets per Panicle}

As presented in Table 13, the number of filled spikelets per panicle was significantly influenced by the concentration of paclobutrazol and its interaction with variety. Elon-elon responded to paclobutrazol concentration but Palawan Red did not, even at higher concentrations. Without paclobutrazol application, Palawan Red had more filled spikelets than Elon-elon, implying genetic variation. At 500 ppm level, Elon-elon out-numbered Palawan Red by 23 spikelets per panicle. This shows that $500 \mathrm{ppm}$ is the best level for Elon-elon as far as number of filled spikelets per panicle is concerned.

Table 13. Number of filled spikelets per panicle as affected by paclobutrazol concentration

\begin{tabular}{cccccc}
\hline Variety & \multicolumn{3}{c}{ Paclobutrazol Concentration } & (ppm ) \\
\cline { 2 - 5 } & 0 & 250 & 500 & 1000 & M ean \\
\hline Elon-elon & $51.55^{\mathrm{d}}$ & $87.20^{\mathrm{ab}}$ & $94.74^{\mathrm{a}}$ & $64.31^{\mathrm{c}}$ & 74.45 \\
Palawan Red & $72.12^{\mathrm{bc}}$ & $77.82^{\mathrm{abc}}$ & $71.49 \mathrm{bc}$ & $81.34 \mathrm{abc}$ & 75.69 \\
M ean & $61.83^{\mathrm{y}}$ & $82.51^{\mathrm{x}}$ & $83.12^{\mathrm{x}}$ & $72.83^{\mathrm{xy}}$ & \\
\hline
\end{tabular}

Means in a column followed by the same letter superscript(s) are not significantly different at $5 \%$ level by DMRT

\section{Percent Filled Grains per Panicle}

Percentage filled spikelets per panicle significantly differed among varieties, concentrations of paclobutrazol and their interaction. Application of paclobutrazol significantly increased percent filled spikelets per panicle in Elon-elon. This is highlighted at $500 \mathrm{ppm}$ level, wherein Elon-elon produced $21.52 \%$ higher percent filled spikelets than 
Palawan Red. It is revealed further that as the level of paclobutrazol is increased, percent filled spikelets per panicle also increased up to $500 \mathrm{ppm}$ only and then declined at $1000 \mathrm{ppm}$ level using the same variety. Meanwhile, Palawan Red did not show a positive response on the application of paclobutrazol.

Table 14. Percent filled spikelets (\%) per panicle as affected by paclobutrazol concentration

\begin{tabular}{cccccc}
\hline Variety & \multicolumn{4}{c}{ Paclobutrazol } & \multicolumn{3}{c}{ Concentration (ppm) } \\
\hline Elon-elon & 0 & 250 & 500 & 1000 & Mean \\
Palawan Red & $63.58^{\mathrm{b}}$ & $79.38^{\mathrm{a}}$ & $80.34^{\mathrm{a}}$ & $72.81^{\mathrm{ab}}$ & $74.03^{\mathrm{A}}$ \\
Mean & $65.37^{\mathrm{Y}}$ & $71.43^{\mathrm{ab}}$ & $66.11^{\mathrm{b}}$ & $74.82^{\mathrm{ab}}$ & $69.88^{\mathrm{B}}$ \\
\hline
\end{tabular}

Means in a column followed by the same letter superscript(s) are not significantly different at $5 \%$ level by DMRT

Weight of 1000 grains, Grain Yield, Dry Matter Yield and Harvest Index

The weight of 1000 grains $(\mathrm{g})$, grain yield (t/ha), dry matter yield ( $\mathrm{t} / \mathrm{ha}$ ) and harvest index of the two traditional varieties as affected by paclobutrazol concentration are presented in Table 15.

Harvest index is the proportion of dry weight of grains to the total dry matter yield. For high yielding varieties, the usual harvest index obtained is about 0.5 . This is indicated by the grain to straw ratio of 0.95 to $1.15 \mathrm{in} \mathrm{N-}$ responsive varieties (Chandler 1969, as cited by Canare, 1998). The harvest index obtained by the two varieties is 0.34 for Elon-elon and 0.35 for Palawan Red. This indicates that the yield level is low in relation to the amount of straw that was produced. These values, however, are acceptable considering so many factors that adversely affected the growth of the plants as well as the inherent characteristics of traditional varieties of being low yielding.

Results further revealed that the weight of 1000 grains (g), grain yield ( $\mathrm{t} / \mathrm{ha}$ ), dry matter yield ( $\mathrm{t} / \mathrm{ha}$ ) and harvest index were not significantly affected by paclobutrazol concentration. However, as regards the weight of 1000 grains of the two traditional varieties Palawan Red had heavier 1000grain weight than Elon-elon with a value of $27.95 \mathrm{~g}$ and $19.85 \mathrm{~g}$, respectively (Table 16). Moreover, the grains of Palawan Red are generally longer and bigger, while Elon-elon are smaller and rounder in appearance, hence, the difference.

It is interesting to note that the incidence of lodging occurred at a later stage of plant growth, that is, when the grains have been already filled with photosynthates. Lodging at this stage may be considered as less critical to yield and though lodging percentage is high on the untreated plants and those that received low levels of paclobutrazol, it has very minimal effect on theyield. 
Table 15. Weight of 1000 grains (g), grain yield ( $\mathrm{t} / \mathrm{ha}$ ), dry matter yield ( $\mathrm{t} / \mathrm{ha}$ ) and harvest index as affected by paclobutrazol concentration

\begin{tabular}{ccccc}
\hline $\begin{array}{c}\text { Paclobutrazol } \\
\text { Concentration }\end{array}$ & Weight & $\begin{array}{c}\text { Grain Dry Matter Harvest } \\
\text { of } 1000\end{array}$ \\
Yield \\
$(\mathrm{ppm})$ & Grains $(\mathrm{g})$ & $(\mathrm{t} / \mathrm{ha})$ & $\begin{array}{c}\text { Yield } \\
(\mathrm{t} / \mathrm{ha})\end{array}$ & Index \\
\hline 0 & 23.21 & 3.43 & 9.62 & 0.33 \\
250 & 24.05 & 3.75 & 10.2 & 0.34 \\
500 & 24.22 & 3.95 & 10.39 & 0.35 \\
1000 & 24.12 & 3.61 & 9.12 & 0.36 \\
\hline
\end{tabular}

The above result is related to the findings at IRRI (2005), that the unlodged plants had 26\% higher grain yield than those that lodged early (at $10 \mathrm{DAF}$ ). The severity of yield loss increased from plants that experienced lodging at late flowering stage (30 DAF) compared with those that lodged during early flowering (10 DAF).

Table 16. Weight of 1000 grains (g), grain yield (t/ha), dry matter yield (t/ha) and harvest index of two traditional rice varieties

\begin{tabular}{ccccc}
\hline & $\begin{array}{c}\text { Weight of } \\
1000\end{array}$ & $\begin{array}{c}\text { Grain } \\
\text { Yield }\end{array}$ & $\begin{array}{c}\text { Dry } \\
\text { Yatter } \\
\text { Yrains }\end{array}$ & $\begin{array}{c}\text { Harvest } \\
\text { Index }\end{array}$ \\
\hline $\begin{array}{c}\text { Elon-elon } \\
\text { Palawan } \\
\text { Red }\end{array}$ & $19.85^{\mathrm{b}}$ & 3.68 & 10.08 & 0.34 \\
\hline
\end{tabular}

Means in a column followed by the same letter superscript(s) are not significantly different at $5 \%$ level by DMRT

Study 2. Effects of Different Levels of Nitrogen on the Agro-morphological and Yield Performance of Different Two Traditional Rice Varieties Applied with Paclobutrazol

\section{Stem Diameter, Culm Length and Plant Height at Maturity}

Presented in Table 17 are the stem diameter $(\mathrm{mm})$, culm length $(\mathrm{cm})$ and plant height $(\mathrm{cm})$ at maturity. Results revealed that stem diameter, culm length and plant height at maturity were not significantly affected by the different levels of nitrogen and their interaction with variety. Elon-elon had significantly bigger stem diameter than Palawan Red which can be attributed to the difference in their genetic make-up. This result is consistent with the findings in study 1 (Table 1 ). 
Table 17. Stem diameter $(\mathrm{mm})$, culm length $(\mathrm{cm})$ and plant height $(\mathrm{cm})$ at maturity as affected by different levels of nitrogen

\begin{tabular}{cccc}
\hline \hline $\begin{array}{c}\text { Level of } \\
\text { Nitrogen } \\
(\mathrm{kg} / \mathrm{ha})\end{array}$ & $\begin{array}{c}\text { Stem } \\
\text { Diameter } \\
(\mathrm{m} \mathrm{m})\end{array}$ & $\begin{array}{c}\text { Culm } \\
\text { Length } \\
\text { (cm) }\end{array}$ & $\begin{array}{c}\text { Plant } \\
\text { Height } \\
\text { (cm) }\end{array}$ \\
\hline 0 & 6.41 & 109.13 & 132.52 \\
30 & 6.32 & 112.38 & 136.01 \\
60 & 6.34 & 113.08 & 137.35 \\
\hline
\end{tabular}

Moreover, this trend is in consonance with the insignificant differences obtained on the lengths of the lower internodes (Table 19). It can be inferred, therefore, that for as long as paclobutrazol is applied at $500 \mathrm{ppm}$, increasing the levels of nitrogen from 0 to $60 \mathrm{~kg} / \mathrm{ha}$ will not result to any increase in stem diameter, culm length and plant height at maturity. This shows that paclobutrazol is effective in inhibiting stem elongation in spite the presence of high nitrogen. This result is in agreement to the findings of Lee and Kim (1988), that culm length was increased as N level increased, but decreased by application of paclobutrazol. Culm length was not affected by $\mathrm{N}$ split rates in Seomjinbyeo and Samgangbyeo varieties. Meanwhile, Yim et al. (1997) found that application of paclobutrazol during the reproductive stage reduces culm length and lodging index at both ordinary and high nitrogen levels.

Table 18. Stem diameter $(\mathrm{mm})$ and culm length $(\mathrm{cm})$ and plant height $(\mathrm{cm})$ at maturity of two traditional rice varieties

\begin{tabular}{cccc}
\hline Variety & $\begin{array}{c}\text { Stem } \\
\text { Diameter } \\
(\mathrm{mm})\end{array}$ & $\begin{array}{c}\text { Culm } \\
\text { Length } \\
(\mathrm{cm})\end{array}$ & $\begin{array}{c}\text { Plant } \\
\text { Height } \\
(\mathrm{cm})\end{array}$ \\
\hline Elon-elon & $6.57^{\mathrm{a}}$ & 111.73 & 136.13 \\
Palawan Red & $6.15^{\mathrm{b}}$ & 111.33 & 134.52 \\
\hline
\end{tabular}

Means in a column followed by the same letter superscript(s) are not significantly different at $5 \%$ level by DMRT

\section{Length of Lower Internodes at Maturity and Lodging Index}

The length of lower internodes at maturity and lodging index as affected by different levels of nitrogen are presented in Table 19. Nitrogen levels from 0 to $60 \mathrm{~kg} / \mathrm{ha}$ did not change the lengths of the lower internodes. The results suggest that internode elongation was limited by paclobutrazol application at the concentration of $500 \mathrm{ppm}$ even when the nitrogen level was increased from zero to $60 \mathrm{~kg} / \mathrm{ha}$. 
Table 19. Length of lower internodes at maturity $(\mathrm{cm})$ and lodging index as affected by different levels of nitrogen

\begin{tabular}{cccccc}
\hline \multirow{2}{*}{$\begin{array}{c}\text { Nitrogen } \\
\text { (kg/ha) }\end{array}$} & First & Second & Third & Fourth & $\begin{array}{c}\text { Lodging } \\
\text { Index }\end{array}$ \\
\cline { 2 - 5 } & 5.15 & 8.13 & 13.28 & 19.36 & $4.67 \mathrm{a}$ \\
30 & 5.39 & 8.48 & 12.74 & 19.05 & $8.33^{\mathrm{b}}$ \\
60 & 4.93 & 8.76 & 12.88 & 18.93 & $8.67 \mathrm{~b}$
\end{tabular}

Means followed by the same letter superscript(s) are not significantly different at $5 \%$ level by DMRT

Palawan Red had significantly longer first, second and fourth internodes than Elon-elon but the varieties had comparable lengths of the third internode. The results are similar to those of study 1 (Tables 3 and 4), which implies that the differences are inherent to the two varieties.

Table 20. Length of lower internodes at maturity $(\mathrm{cm})$ and lodging index of two traditional rice varieties

\begin{tabular}{cccccc}
\hline & \multicolumn{4}{c}{ Length of Internodes Lodging } & \\
\cline { 2 - 5 } Variety & First & Second & Third & Fourth & Index \\
\hline $\begin{array}{c}\text { Elon-elon } \\
\text { Palawan }\end{array}$ & $4.36^{\mathrm{a}}$ & $7.35^{\mathrm{a}}$ & 12.01 & $17.66^{\mathrm{a}}$ & 6.78 \\
\begin{tabular}{c} 
Red \\
\hline
\end{tabular} & $5.95^{\mathrm{b}}$ & $9.56^{\mathrm{b}}$ & 13.92 & $20.56^{\mathrm{b}}$ & 7.67 \\
\hline
\end{tabular}

Means in a column followed by the same letter superscript(s) are not significantly different at $5 \%$ level by DMRT

In terms of lodging index, lodging in rice usually results from the bending or buckling of the two lowest internodes, which have elongated more than $40 \mathrm{~cm}$. The strength of the elongated internodes is affected by the mechanical strength, chemical composition and plant nutritional status (Yoshida, 1981). Results disclosed that application of increasing levels of nitrogen increased the lodging index of traditional rice varieties. Lodging index significantly increased from 4.67 to 8.33 due to the application of $30 \mathrm{~kg} \mathrm{~N} / \mathrm{ha}$. Further increase in nitrogen to $60 \mathrm{~kg} / \mathrm{ha}$ resulted to a lodging index of 8.67 , this is $85.65 \%$ higher than the untreated plants. No significant difference on lodging index between the two varieties was obtained.

The above results are in agreement with the findings of Stevens and Tanner (1999). They mentioned that when Baldo rice variety was applied with nitrogen rates less than $100 \mathrm{lbs}$./acre, lodging was three per cent and lower. As nitrogen rates increased over $100 \mathrm{lbs}$./acre, small increases in fertilizer caused increases in lodging percentage. An increase from 120 lbs./acre of nitrogen to $150 \mathrm{lbs}$. caused lodging to increase significantly from $39 \%$ to $82 \%$.

Correlation analysis disclosed a positive relationship between the levels of nitrogen and lodging index. As the level of nitrogen increased from 
0 to $60 \mathrm{~kg} / \mathrm{ha}$, lodging incidence also increased (Correlation coefficient = $0.6573)$.

\section{Leaf Area Index and Number of Unproductive Tillers per Hill}

Table 21 presents the LAI and number of unproductive tillers per hill of the two traditional varieties. Analysis of variance disclosed nonsignificant differences on LAI and number of unproductive tillers per hill at all levels of nitrogen while significant differences occurred among varieties on LAI. As dictated by their genetic make-up, Palawan Red had higher LAI than Elonelon. The inherent character of Palawan Red of having long and broader leaves caused the significant difference on their leaf area.

Table 21. Leaf area index and unproductive tillers per hill of two traditional rice varieties

\begin{tabular}{ccc}
\hline Variety & $\begin{array}{c}\text { Leaf Area } \\
\text { Index }\end{array}$ & Unproductive Tiller Per Hill \\
\hline Elon-elon & $3.78^{\mathrm{b}}$ & 1.0 \\
Palawan Red & $4.99^{\mathrm{a}}$ & 2.0 \\
\hline
\end{tabular}

\section{Number of Productive Tillers per Hill}

The number of productive tillers per hill was highly significantly affected by variety and significantly by the interaction between variety and levels of nitrogen. Overall, Elon-elon produced more productive tillers with a value of 15.90 than Palawan Red, with only 10.64. At lower rates of nitrogen $(0-30 \mathrm{~kg})$, the number of productive tillers produced by the two varieties were comparable. At $60 \mathrm{~kg} \mathrm{~N} / \mathrm{ha}$, Palawan Red produced highly significantly fewer productive tillers/hill than Elon-elon with a value of 7.23. This value corresponds to $122 \%$ reduction in productive tillers. This result may be explained by the higher LAI of Palawan Red than Elon-elon, causing shading and tiller mortality. Lei and Wang (1961) as cited by Nguyen et al. (2004) mentioned that increasing the LAI increased shading and tiller mortality and is associated with reduced tillering rate in rice crops. Likewise, Yoshida (1981) mentioned that under low light conditions, some of the tiller buds may not develop into tillers because of lack of carbohydrate necessary for growth. 
Table 22. Number of productive tillers per hill as affected by different levels of nitrogen and variety

\begin{tabular}{ccccc}
\hline \multirow{2}{*}{ Variety } & \multicolumn{3}{c}{ Levels of Nitrogen (kg/ha) } & \\
\cline { 2 - 4 } & 0 & 30 & 60 & M ean \\
\hline Elon-elon & $17.0^{\mathrm{a}}$ & $15.0^{\mathrm{a}}$ & $16.0^{\mathrm{a}}$ & $16.0^{\mathrm{A}}$ \\
Palawan Red & $12.0^{\mathrm{a}}$ & $13.0^{\mathrm{a}}$ & $7.0^{\mathrm{b}}$ & $11.0^{\mathrm{B}}$ \\
Mean & 15.0 & 14.0 & $12.0^{\circ}$ & \\
\hline
\end{tabular}

Means in a column followed by the same letter superscript(s) are not significantly different at $5 \%$ level by DMRT

Thus, application of nitrogen to the two traditional varieties had no advantage in terms of number of productive tillers; it is even detrimental to Palawan Red at $60 \mathrm{~kg} / \mathrm{ha}$.

Panicle Length, Number of Filled and Unfilled spikelets and Number of Spikelets per Panicle

As presented in Table 23, panicle length $(\mathrm{cm})$, number of filled and unfilled spikelets and number of spikelets per panicle were not significantly affected by level of nitrogen and its interaction with variety. The results again show an absence of response to nitrogen, similar to that of LAI and number of productive tillers. The panicle of Elon-elon was significantly longer than that of Palawan Red (Table 24). This result is similar to that of study 1 (Table 17), indicating that the result could be a varietal characteristic.

Table 23. Panicle length $(\mathrm{cm})$, number of filled and unfilled spikelets and number of spikelets per panicle as affected by different levels of nitrogen

\begin{tabular}{|c|c|c|c|c|}
\hline $\begin{array}{c}\text { Level of } \\
\text { Nitrogen } \\
(\mathrm{kg} / \mathrm{ha})\end{array}$ & $\begin{array}{l}\text { Panicle } \\
\text { Length } \\
(\mathrm{cm})\end{array}$ & $\begin{array}{c}\text { Number } \\
\text { of } \\
\text { Filled } \\
\text { Spikelets } \\
\text { /Panicle } \\
\end{array}$ & $\begin{array}{c}\text { Number } \\
\text { of } \\
\text { Unfilled } \\
\text { Spikelets } \\
\text { /Panicle }\end{array}$ & $\begin{array}{c}\text { Number } \\
\text { of } \\
\text { Spikelets / } \\
\text { Panicle } \\
\end{array}$ \\
\hline 0 & 23.39 & 50 & 37 & 87 \\
\hline 30 & 23.63 & 46 & 47 & 93 \\
\hline 60 & 24.37 & 38 & 48 & 86 \\
\hline
\end{tabular}

Table 24. Panicle length (cm), number of filled and unfilled spikelets and number of spikelets per panicle of two traditional rice varieties

\begin{tabular}{ccccc}
\hline & $\begin{array}{c}\text { Panicle } \\
\text { Length } \\
\text { (cm) }\end{array}$ & $\begin{array}{c}\text { Number of } \\
\text { filled } \\
\text { Spikelets } \\
\text { /Panicle }\end{array}$ & $\begin{array}{c}\text { Number } \\
\text { of Unfilled } \\
\text { Spikelets } \\
\text { /Panicle }\end{array}$ & $\begin{array}{c}\text { Number } \\
\text { of } \\
\text { Spikelets } / \\
\text { Panicle }\end{array}$ \\
\hline $\begin{array}{c}\text { Elon-elon } \\
\text { Palawan } \\
\text { Red }\end{array}$ & $24.4 \mathrm{a}$ & $55.0 \mathrm{a}$ & $37.0 \mathrm{a}$ & 92 \\
& $23.19 \mathrm{~b}$ & $35.0 \mathrm{~b}$ & $51.0 \mathrm{a}$ & 86
\end{tabular}

Means in a column followed by the same letter superscript(s) are not significantly different at $5 \%$ level by DMRT 
The two varieties produced comparable number of spikelets per panicle. However, Elon-elon had significantly more filled spikelets but fewer unfilled spikelets per panicle than Palawan Red. Elon-elon was better able to fill the spikelets than Palawan Red.

Grain filling is perceived to be highly vulnerable to adverse environmental conditions like strong wind, high rainfall, low solar radiation and lodging. When conditions are not favorable, grain filling is reduced. Yoshida and Parao (1976) as cited by Yoshida, (1981) reported that lodging or culm bending decreases filled-spikelet percentage. Lodging reduces the cross-sectional area of vascular bundles and disturbs the movement of assimilates and absorbed nutrients via the roots. It also disturbs the leaf display and increases shading.

There was strong rain during the flowering of Palawan Red but not during the flowering of Elon-elon. Palawan Red also lodged earlier than Elon-elon. Strong rains during flowering as well as early lodging reduced the capacity of Palawan Red to fill the spikelets, resulting to fewer filled spikelets and more unfilled spikelets than Elon-elon.

\section{Percent Filled Spikelets per Panicle and Weightof1000 Grains}

Increasing the level of nitrogen from 0 to $60 \mathrm{~kg} / \mathrm{ha}$ did not improve percent filled spikelets and 1000-grain weight of the two varieties tested (Table 25). Insignificant interaction was likewise obtained between variety and levels of nitrogen. However, there were significant differences between the two varieties in the same variables. Elon-elon produced significantly higher percent filled spikelets per panicle with $>60 \%$ than Palawan Red, which only produced $39.21 \%$ (Table 26 ). As stated under number of filled spikelets, this can be due to strong rains during flowering as well as early lodging of Palawan Red.

Table 25. Percent filled spikelets (\%) per panicle and weight of 1000 grains ( $\mathrm{g}$ ) as affected by different levels of nitrogen

\begin{tabular}{ccc}
\hline \hline $\begin{array}{c}\text { Level of } \\
\text { Nitrogen } \\
(\mathrm{kg} / \mathrm{ha})\end{array}$ & $\begin{array}{c}\text { Percent Filled } \\
\text { Spikelets } \\
\text { /Panicle (\%) }\end{array}$ & $\begin{array}{c}\text { Weight of } 1000 \\
\text { Grains }(\mathrm{g})\end{array}$ \\
\hline 0 & 57.84 & 22.33 \\
30 & 47.3 & 21.62 \\
60 & 44.82 & 20.30 \\
\hline \hline
\end{tabular}


Table 26. Percent filled spikelets per panicle and weight of 1000 grains (g) of two varieties as affected by different levels of nitrogen

\begin{tabular}{ccc}
\hline Variety & $\begin{array}{c}\text { Percent Filled } \\
\text { Spikelets/Panicle(\%) }\end{array}$ & $\begin{array}{c}\text { Weight of } 1000 \\
\text { Grains (g) }\end{array}$ \\
\hline Elon-elon & $60.76^{\mathrm{a}}$ & $18.73^{\mathrm{b}}$ \\
Palawan Red & $39.21^{\mathrm{b}}$ & $24.10^{\mathrm{a}}$ \\
\hline \hline
\end{tabular}

Means in a column followed by the same letter superscripts(s) are not significantly different at $5 \%$ level by DMRT

Elon-elon had lighter 1000-grain weight with a value of 18.73 grams while Palawan red had 24.10 grams. As mentioned earlier, the difference in the 1000-grain weight may be attributed to the difference in genetic makeup of the two varieties tested.

It is worthwhile mentioning that plants in study 2 lodged earlier than the plants in study 1 . This resulted to the reduction on the weight of 1000 grains of the plants in study 2 .

\section{Grain Yield}

The yield of traditional rice varieties applied with paclobutrazol as affected by different levels of nitrogen is presented in Table 27. Analysis of variance disclosed highly significant differences in yield among nitrogen levels and between the two varieties. There were no interaction effects. Elon-elon out-yielded Palawan Red by $57.83 \%$ (Table 27). This again can be explained by the strong rain during flowering and the early lodging of Palawan Red, which reduced its number of filled spikelets. Furthermore, Palawan Red had fewer productive tillers.

Table 27. Grain yield ( $\mathrm{t} / \mathrm{ha}$ ) of two traditional varieties as affected by different levels of nitrogen

\begin{tabular}{lcccc}
\hline \multirow{2}{*}{ Variety } & \multicolumn{2}{c}{ Level of Nitrogen } & $(\mathrm{kg} / \mathrm{ha})$ & \\
\cline { 2 - 4 } & 0 & 30 & 60 & Mean \\
\hline Elon-elon & 3.60 & 2.43 & 2.73 & $2.92^{\mathrm{A}}$ \\
Palawan Red & 3.37 & 1.42 & 0.76 & $1.85^{\mathrm{B}}$ \\
Mean & $3.48^{\mathrm{x}}$ & $1.92^{\mathrm{Y}}$ & $1.75^{\mathrm{Y}}$ & \\
& & & & \\
\hline \hline
\end{tabular}

Means in a column followed by the same letter superscript(s) are not significantly different at $5 \%$ level by DMRT

Plants which were not applied with $\mathrm{N}$-fertilizer yielded 3.48 tons/ha. Applying $30 \mathrm{~kg} \mathrm{~N} /$ ha decreased the yield of rice by $44.82 \%$ over the unfertilized plants. Further increase in nitrogen to $60 \mathrm{~kg} / \mathrm{ha}$ did not reduce the yield further. The trend is similar to that of lodging index (Table 20). 
It is interesting to note that lodging incidence and yield are negatively correlated $(r=-0.7328)$. This connotes that as lodging index increases, the yield of rice decreases. When the plants lodged, the translocation of photosynthates from source to sink is affected resulting to low yield.

As mentioned by Berry et al. (2004), lodging has been responsible for limiting the yieldand the potential for increases in yields as well as lossesin eventual and harvestable yields in cereals globally. In rice, yield losses can be up to $80 \%$ and can cause severe knock-on effects, including reduced grain quality and greater drying cost. Roy and Jha (1985), assessed the yield loss due to lodging caused by high winds in four dwarf and two tall varieties with different growth periods. Loss was least $(18.2 \%)$ in the dwarf Sujata (growth period 135-140 days), when lodging occurred 10 days after flowering; when lodging occurred at flowering in this variety, yield loss was $35.7 \%$. Lodging occurred before or at flowering, or at booting in the other varieties and resulted in losses of $23.6-55.1 \%$.

Dry Matter Yield

Dry matter yield of the plants as affected by the different levels of nitrogen, variety and their interaction showed highly significant differences between variety, levels of nitrogen and their interaction. Without nitrogen application, the dry matter yields of the two varieties were comparable. At 30 and $60 \mathrm{kgN} / \mathrm{ha}$, Palawan Red produced highly significantly lower dry matter yield than Elon-elon. The dry matteryield of Elon-elon was not reduced by nitrogen application even up to $60 \mathrm{~kg} / \mathrm{ha}$. As mentioned earlier, strong rains during flowering as well as early lodging have adversely affected the overall growth of Palawan Red. Vegetative parts of the lodged plants adhered to the soil causing rapid deterioration, thereby lowering the straw yield. In addition, grain yield was also affected as shown in Table 27.

Table 28. Dry matter yield (t/ha) as affected by different levels of nitrogen and variety

\begin{tabular}{ccccc}
\hline Variety & \multicolumn{3}{c}{ Levels of Nitrogen } & $(\mathrm{kg} / \mathrm{ha})$ \\
\hline \multicolumn{5}{c}{} \\
\hline Elon-elon & $10.28^{\mathrm{a}}$ & $9.60^{\mathrm{a}}$ & $10.30^{\mathrm{a}}$ & Mean \\
\hline Palawan Red & $9.82^{\mathrm{a}}$ & $6.99^{\mathrm{b}}$ & $5.25^{\mathrm{b}}$ & $7.35^{\mathrm{B}}$ \\
Mean & $10.05^{\mathrm{x}}$ & $8.29^{\mathrm{y}}$ & $7.78^{\mathrm{Y}}$ & \\
\hline \hline
\end{tabular}

Means followed by the same letter superscript(s) are not significantly different at $5 \%$ level by DMRT

\section{Harvest Index}

Harvest index was highly significantly affected by the levels of nitrogen while significantly affected by variety. Elon-elon had significantly higher harvest index than Palawan Red. Both the grain yield and dry matter 
yield of Palawan Red were lower than those of Elon-elon but the degree of reduction in grain yield was greater than that of dry matter yield, resulting in a lower harvest index. The same is true with the effect of nitrogen level. The amount of grains harvested per unit dry matter yield is very low and with decreasing trend as the level of nitrogen is increased. This is exhibited by a correlation value of -0.7133 .

Table 29. Harvest index of two traditional varieties as affected by different levels of nitrogen

\begin{tabular}{cllll}
\hline Variety & \multicolumn{3}{c}{ Levels of Nitrogen (kg/ha) } & Mean \\
& 0 & 30 & 60 & \\
\hline Elon-elon & 0.32 & 0.23 & 0.24 & $0.26 \mathrm{~A}$ \\
Palawan Red & 0.31 & 0.19 & 0.14 & $0.21 \mathrm{~B}$ \\
Mean & $0.32 \mathrm{X}$ & $0.21 \mathrm{Y}$ & $0.19 \mathrm{Y}$ &
\end{tabular}

Means followed by the same letter superscript(s) are not significantly different at $5 \%$ level by DMRT

\section{CONCLUSION}

The application of paclobutrazol to the traditional rice varieties Elonelon and Palawan Red is effective in shortening the length of the lower internodes and in inhibiting stem elongation resulting to shorter plants with increased lodging resistance. This ultimately produced higher yield than those plants that lodged. However, the application of high rates of nitrogen reduced culm strength causing significant increase in lodging index.

The time of lodging is crucial in predicting the yield performance of the rice plants. Early lodging resulted to huge reduction in yield but little or no effect on yield when it occurs at later stages of the rice crop.

\section{RECOMMENDATION}

Paclobutrazol has been proven to be effective in shortening the height of rice as well as improving its lodging resistance at the recommended rate of N. Paclobutrazol should be sprayed at a concentration of 500 to 1000 ppm to achieve the best result of increasing the lodging resistance of rice.

\section{REFERENCES}

AKITA, S.F., T. PARAO and V.P. CORONEL. 1987. Physiological Responses of Rice to Light and to Nitrogen in Weather. pp. 81-91. IRRI, Los Banos, Laguna.

BERRY P.M., M. STERLING, SPINK, J.H. BAKER, C.J. SYLVESTER-BRADLEY, R. MOONEY, S.J. TAMS and A.R. ENNOS. 2004. Understanding and reducing lodging in cereals. Advances in Agronomy 84:217-271. 
CANARE, J. JR. G. 1998. Fertilizer management of upland rice (Oryza sativa L.) grown on lahar deposit. PhD, Institute of Graduate Studies, Central Luzon State University, Science City of Munoz, Nueva Ecija. Unpublished dissertation.

GOMEZ, K.A. 1972. Techniques for Field Experiments with Rice. International Rice Research Institute, Los Baños, Laguna, Philippines. pp.48.

GOMEZ, K.A. and A.A. GOMEZ. 1984.Atatistical Procedures for Agricultural Research. $2^{\text {nd }}$ Edition International Rice Research Institute. Los Banos, Laguna, Philippines.pp. 89.

IM, I. B., S.Y. LEE, and J.H. KIM. 1988. Effect of paclobutrazol application on the growth and characters related with lodging of paddy rice plant. Korean J. Weed Sci. 8(3): 324-329, ill. Ref. Dec. 1988.

IM, I. B., LEE, S.Y. and M.S.LIM. 1987. Growth and lodging of paddy rice as affected by paclobutrazol application under the different level of nitrogen fertilizer. Korean J. Weed Sci. 7(2): 171-178, ill. Ref. Oct. 1987.

INTERNATIONAL RICE RESEARCH INSTITUTE. 1988. Standard Evaluation System for Rice. $3^{\text {rd }}$ Edition, Los Banos, Laguna, Philippines. pp 123.

LANSIGAN, F.P, W.L. DELOS SANTOS AND J.O. CODILLA. 2000. Agronomic impacts of climate variability on rice production in the Philippines. Agriculture, Ecosystems and Environment 82 (2000) 129-137

LEE, S. S.; and T.J. KIM. 1988. Lodging related traits and yield of two rice varieties as affected by paclobutrazol at different $\mathrm{N}$ levels and split rates. Korean Journal of Weed Science. v. 8(1) pp. 64-70.

MAHBUB, M. A., M. KHANAM, M. S. RAHMAN, A. HOSSAINI and A. R. OMOSTA. 2006. Determination of lodging characters of some brri recommended rice varieties at three nitrogen levels during wet season in Bangladesh. Bangladesh J. Bot. 35(2): 117-124, 2006.

MENGEL, K. and E.A KIRKBY. 1987. Principles of Plant Nutrition. $4^{\text {th }}$ Edition. Worblaufen-Bern/Switzerland: Land Druck AG, Liebefeld/Brn.

NGUYEN, V.Q., P.S TAN, C.V. HACH, V.D. PHAM and X. ZHONG. 2004. Healthy rice canopy for optimal production and profitability. Omon rice. 12:6974.

PHILIPPINE RICE RESEARCH INSTITUTE. 2007. Field Operations Manual. Maligaya, Science City of Munoz, Nueva Ecija, Philippines. pp 121.

ROY, B., and J.N., JHA. 1985. Effect of time of lodging on rice productivity. IRRI Newsletter.

STEVENS G. and E. TANNER. 1999. Effects of Nitrogen on Baldo Rice Missouri Rice Research Update, February 1999.

STREET, J.E., J. H. JORDAN, M. W. EBELHAR and D. L. BOYKIN. 1986. Plant Height and Yield Responses of Rice to Paclobutrazol. American Society of Agronomy. Journal of Natural Resources and Life Sciences Education. Retrieved on June 24, 2010. http:/scidirect.com. 
UENO, H.; P. FRENCH, A. KOHLI, and H. MATSUYUKI. 1987. Paclobutrazol: control of lodging of rice in Japan. In: Proc. 11th International Congress of Plant Protection, Manila, 1987, ed. by E. D. Magallona, Vol. 1, pp. 440444, illus. Ref. [Manila: Pest Control Council of the Philippines, et al.].

UENO, H.; and A. KOHLI. 1994. Paclobutrazol: Control of Rice Lodging in Japan. In:Presentations to the 1987 British Crop Protection Conference - Weeds and the 11th International Congress of Plant Protection, pp. 109-118, illus. Ref. Craydon, Eng., British Crop Protection Council, 1987. http://ricelib.irri.cgiar.org81/search/.

WANG X.I. 1991. Effects of MET on IAA-oxidase and endogenous IAA in Rice. Acta Agricultural University Zhejiangensis, 17(1), 60-64.

WANG X. T., G. LONGXING, Y. CHENGWEI, and W.FUDE.1986. C h e $\mathrm{m}$ i c a l control of the overgrowing seedlings in the continuous cropping of late rice ?. Effects of MET on the growth and tillering of rice seedling and the yield of rice grain. Retrieved on January 3, 2011. http://en.cnki.com.cn/article_en/cjfdtotal-xbzw198802000.htm.

YIM, K.O., Y. W. KWON and D. E. BAYER. 1997. Growth Responses and Allocation of Assimilates of Rice Seedlings by Paclobutrazol and Gibberellin Treatment. Journal of Plant Growth Regulation. Springer New York. Volume 16, Number 1.

YOSHIDA S. 1981. Fundamentals of Rice Crop Science. International Rice Research Institute. Los Banos Laguna, Philippines: pp 269. 